\title{
Risk of acute myeloid leukaemia and multiple myeloma in workers exposed to benzene
}

\author{
Otto Wong
}

\begin{abstract}
Objective-To determine the risk of developing acute myeloid leukaemia (AML) and multiple myeloma in a cohort of workers exposed to benzene. The results were used to show the importance of taking specificity of disease into consideration in causation analysis.

Methods-Data were derived from a cohort of workers employed at two Goodyear plants in Ohio in the manufacture of Pliofilm. Based on data in the Pliofilm study, several papers that examined the relation between exposure to benzene and leukaemia (all cell types combined) have been published. In the current analyses based on updated data in the study, standardised mortality ratios (SMRs) and 95\% confidence intervals (95\% CIs) were calculated for AML and multiple myeloma by cumulative exposure to benzene. The results based on AML were compared with those for leukaemia (all cell types combined) published previously.

Results-An exposure response relation
\end{abstract} was shown between cumulative exposure to benzene and AML. No increased risk of AML was detected for cumulative exposure to benzene below 200 ppm-years (SMR 0.91). Above 200 ppm-years, risk of AML rose drastically; reaching a significant SMR of $98 \cdot 37$ for $>400 \mathrm{ppm}$ years. For multiple myeloma, no relation with exposure to benzene was detected. Conclusion-Analysis specific to AML shows the importance of taking specificity of disease into consideration in causation analysis. This investigation shows that previous analyses based on all leukaemia cell types combined have incorrectly set the estimated threshold too low, and have underestimated risk above the threshold. Current regulatory policies that rely on previous analyses based on all leukaemia cell types combined should be re-examined.

Applied Health

Sciences, 181 Second Avenue, Suite 628, PO Box 2078, San Mateo, California 94401, USA O Wong

Correspondence to: Correspondence to: Dr Otto Wong, Applied Health Sciences, 181 , 628 Second Avenue, Suite 628,
PO Box 2078, San Mateo, PO Box 2078, San Matee,
California 94401, USA. Accepted 13 February 1995
(Occup Environ Med 1995;52:380-384)

Keywords: acute myeloid leukaemia; multiple myeloma; benzene; epidemiology

The cohort of workers employed at two Goodyear plants in Ohio in the manufacture of Pliofilm (rubber hydrochloride) has been the subject of several epidemiological analyses. The first analysis based on mortality (only $75 \%$ complete) up to 1975 was reported by Infante et al. ${ }^{1}$ Infante et al reported a significantly increased standardised mortality ratio (SMR) of 2.60 for lymphatic and haematopoietic cancers. They stated that the increase was due almost entirely to an excess of deaths from leukaemia. For leukaemia, the SMR was $5 \cdot 06$. Recognising that leukaemias related to benzene were predominantly acute myeloid leukaemia (AML), ${ }^{2}$ Infante et al made an attempt to estimate risk by cell type, and estimated the risk of dying from myeloid or monocytic leukaemia to be about 10-fold. Rinsky et al reported the second analysis based on mortality ( $98 \%$ complete) up to $1975 .^{3}$ The results were essentially the same (SMR for lymphatic and haematopoietic cancers 3.30, SMR for leukaemia 5.60). The third analysis was based on mortality up to 1981.4 Analyses by estimated cumulative exposure to benzene were conducted. For the entire cohort, a significantly increased risk of leukaemia of 3.37 was reported. The predominant cell type was AML. A positive exposure-response relation between leukaemia and cumulative exposure to benzene was shown. The accuracy of the exposure estimates used by Rinsky et $a l^{4}$ was questioned. ${ }^{56}$ It seemed that at least some exposures of Rinsky et $\mathrm{al}^{4}$ had been underestimated. As well as leukaemia, a risk of multiple myeloma of borderline significance was reported (SMR 3.98) by Rinsky et $a l,{ }^{4}$ but no exposure-response relation was shown for multiple myeloma.

Paxton et al presented the latest analysis of the Pliofilm cohort based on mortality up to $1987 .{ }^{78}$ As well as exposure estimates developed by Rinsky et al, ${ }^{4}$ Paxton et al used exposure estimates developed by Crump and Allen ${ }^{5}$ and Paustenbach et al. ${ }^{6}$ For the entire cohort, a significantly increased SMR of 3.60 for leukaemia was reported. Furthermore, a positive exposure-response relation was found, although the values of risk ratios by exposure varied with the particular set of exposure estimates used. Paxton et al concluded that the leukaemia data were consistent with a threshold model, and suggested that the threshold would be greater than 50 ppm-years. ${ }^{78}$ Although no quantitative risk analysis was performed for multiple myeloma because no additional case was found in the update, Paxton et al concluded that the statistical association previously reported by Rinsky et $a l^{4}$ would have been "weakened to nonsignificance." 78 
The focus of the analyses of Paxton et al was on the difference between the three sets of exposure estimates. ${ }^{78}$ The difficulties of estimating exposure in epidemiological studies, in the absence of historical exposure data, are well recognised. In the Pliofilm study, it seemed that some of the estimates of Rinsky et al were low. ${ }^{4}$ On the other hand, Utterback and Rinsky ${ }^{9}$ commented that some estimates developed by Crump and Allen ${ }^{5}$ or Paustenbach et $a l^{6}$ were high. It seems unlikely that the discrepancies among the three sets of exposure estimates will ever be resolved completely.

As well as exposure estimates, another important aspect of risk analysis is the proper classification of specific health outcomes. Paxton et al analysed leukaemia data as a single disease. In the past, leukaemia was considered to be a single statistical category in most occupational epidemiological studies, partly because of the historical nomenclature, potential misdiagnoses in some cases, lack of an understanding of the biological mechanisms, unavailability of cell type specific rates for comparison, and most importantly, the paucity of cases by cell type in individual studies. ${ }^{1011}$ Recently epidemiological studies have shown the importance of cell type specific analysis in studying leukaemia. It has now been recognised that the diseases collectively known as leukaemia are several distinct malignancies with different aetiological factors. For example, Linet began her book on leukaemia with the following:

Earlier epidemiologic reviews considered leukemia as a single disease with some minor differences in risk factors for each of the histopathologic types. In the last two decades, epidemiologic studies have provided evidence that diseases collectively identified as leukemia are several distinct malignancies characterized by varying age, sex, race, and ethnic group patterns, dissimilar secular trends, and different etiologic factors. ${ }^{12}$

Likewise, Heath began a review on leukaemia with the following:

The leukemias encompass a diverse group of malignancies that share in common merely the fact that all arise from cell systems that circulate in peripheral blood and that arise in large part from bone marrow. The differing cell origins of the leukemias require that different leukemic cell types be considered separately in terms of etiology, pathogenesis, therapy, and prevention. ${ }^{13}$

Similarly, the diversity of different types of leukaemia has long been recognised by haematologists, as indicated, for example, in the widely used textbook of haematology by Wintrobe et al:

Few authorities would disagree concerning the recognition of chronic myeloid leukemia (CML), acute myeloid leukemia (AML), polycythemia vera (PV), idiopathic myelofibrosis (IMF), chronic lymphocytic leukemia (CLL), acute lymphoblastic leukemia (ALL), Hodgkin's disease (HD), the nonHodgkin's lymphomas (NHL), multiple myeloma (MM), and macroglobulinemia as distinct entities. $^{14}$

The issue of whether all leukaemia cell types can be affected by a common aetiological agent has also been examined at the cellular level. In particular, the role of haemopoietic stem cells in leukaemogenesis has been investigated. Stem cells can be classified into two major categories: the pluripotential stem cells, which are responsible for the production of circulating elements; and their direct descendants, the committed precursor cells, which are programmed to follow a single line of differentiation. Both in vivo and in vitro studies have indicated that the committed stem (precursor or progenitor) cells are capable of self renewal and amplification. In the past, several proposed hypotheses have suggested that the effects of benzene metabolites on stem cells have a major impact on cell proliferation and differentiation during the early stages of leukaemogenesis. In most of these hypotheses little or no distinction was made between the pluripotential and the committed stem cells. Recent research has indicated that the committed stem cells or progenitor cells play an important part not only in the maintenance of normal, steady state haemopoiesis but also in the aetiology of cell type specific leukaemias.

Based on an investigation of immunoglobulin gene organisation and expression in haemopoietic stem cell leukaemia, Ford et al have shown that a clonal event leading to blast crisis can occur in a committed B cell precursor rather than in the pluripotential stem cell precursor. ${ }^{15}$ Based on human DNA analyses, Maher et al concluded that CML and CLL do not arise from a common progenitor and that these malignancies arise from two distinct precursors. ${ }^{16}$

Laboratory investigations of the effects of benzene and its metabolites on stem and progenitor cell regulation by Irons et al have offered a mechanistic explanation for the selective increase in AML. ${ }^{17}$ The investigations have shown that benzene in vivo and hydroquinone (a benzene metabolite) in vitro alter the recruitment or stimulation of myeloid progenitor cells, thereby increasing the number of cells at risk of developing leukaemia. Furthermore, these investigations have indicated that this effect is selective for recruitment of myeloid cells that respond to a specific myeloid growth factor, GM-CSF. This effect, on the other hand, is not found for other growth factors associated with recruitment or stimulation of lymphoid progenitor cells.

Thus, recent advances in other disciplines confirm the epidemiological observation that leukaemia is a group of distinct malignancies that should be analysed separately. As commented previously, ${ }^{10} 11$ very few individual studies have estimates of exposure to benzene and can provide enough cases for leukaemia cell type specific analysis. In terms of AML, the possible exception is the Pliofilm study. In here, I present an analysis specific to AML based on the Pliofilm study, which shows that such a specific analysis provides more appropriate estimates both for a threshold and for risk ratios above the threshold than analyses based on all leukaemia cell types combined. Also, I present an analysis for multiple myeloma by cumulative exposure to benzene. 


\section{Results and analyses}

The analyses were based on the Pliofilm study updated up to 1987, as reported by Paxton et al. ${ }^{78}$ Age specific rates for AML and multiple myeloma derived from data provided by the National Center for Health Statistics and by the National Cancer Institute were used in computing expected deaths. Standardised mortality ratios and $95 \%$ confidence intervals (95\% CIs) were calculated. Only exposure estimates developed by Rinsky et al $^{4}$ and their exposure categories were used in the analyses.

Table 1 shows that, for the cohort as a whole, six deaths from AML were observed, compared with 1.19 expected. The corresponding SMR of 5.03 was significant (95\% CI 1.84-10.97). No increase of AML was detected for cumulative exposure below 200 ppm-years. Among workers whose cumulative exposure was less than $200 \mathrm{ppm}$-years, one death from AML was observed, compared with 1.09 expected (SMR 0.91), but, above 200 ppm-years, risk of AML rose drastically. For workers with a cumulative exposure of $>400$ ppm-years, their SMR for AML was 98.37.

Table 2 shows the results of a similar analysis for multiple myeloma. For the cohort as a whole, four deaths from multiple myeloma were observed, compared with 1.37 expected. The SMR of 2.91 was not significant. More importantly, table 2 indicates that there was no exposure-response relation. In fact, three of the four deaths were in the lowest exposure category. One of these three people was employed at one of the plants for only four days, and the other two for nine months and 1.5 years. $^{4}$

\section{Discussion}

Paxton et al provided exposure-response analyses for overall leukaemia (all cell types

Table 1 Acute myeloid leukemia by cumulative exposure to benzene

\begin{tabular}{|c|c|c|c|}
\hline \multirow{2}{*}{$\begin{array}{l}\text { Cumulative } \\
\text { exposure } \\
\text { (ppm-years) }\end{array}$} & \multicolumn{2}{|c|}{ Deaths } & \multirow[b]{2}{*}{$S M R(95 \% C I)$} \\
\hline & Obs & $\operatorname{Exp}$ & \\
\hline $\begin{array}{l}<40 \\
40-200 \\
200-400 \\
>400 \\
\text { Total }\end{array}$ & $\begin{array}{l}1 \\
0 \\
2 \\
3 \\
6\end{array}$ & $\begin{array}{l}\left.\begin{array}{l}0.84 \\
0.25 \\
0.07 \\
0.03 \\
1.19\end{array}\right\} 1.09 \\
-19\end{array}$ & $\begin{array}{l}\left.\begin{array}{l}1 \cdot 19 \\
0\end{array}\right\} 0 \cdot 91 \begin{array}{l}(0 \cdot 03-6 \cdot 63) \\
(0-14 \cdot 75)\end{array} \\
27 \cdot 21^{\star \star}(3 \cdot 29-98 \cdot 24) \\
98 \cdot 37^{\star \star}(20 \cdot 28-287 \cdot 65) \\
5 \cdot 03^{\star \star}(1 \cdot 84-10 \cdot 97)\end{array}$ \\
\hline
\end{tabular}

Table 2 Multiple myeloma by cumulative exposure to benzene

\begin{tabular}{lllc}
\hline $\begin{array}{l}\text { Cumulative } \\
\text { exposure } \\
\text { (ppm-years) }\end{array}$ & Deaths & & \\
\cline { 2 - 3 } & Obs & Exp & $S M R(95 \% C I)$ \\
\hline$<40$ & 3 & 0.93 & $3 \cdot 21(0 \cdot 66-9 \cdot 39)$ \\
$40-200$ & 0 & 0.30 & $0(0-12 \cdot 29)$ \\
$200-400$ & 0 & $0 \cdot 10$ & $0(0-36 \cdot 89)$ \\
$>400$ & 1 & 0.04 & $25 \cdot 17(0 \cdot 63-139 \cdot 83)$ \\
Total & 4 & 1.37 & $2 \cdot 91(0 \cdot 79-7 \cdot 45)$ \\
\hline
\end{tabular}

combined) based on three sets of exposure estimates. ${ }^{78}$ In particular, their analysis based on the exposure estimates of Rinsky et $a l^{4}$ indicated that the risk of leukaemia was increased for every cumulative exposure category, with SMRs of $1.97,2 \cdot 29,6.93$ (significant), and 20.00 for exposure categories $0-5$, $5-50,50-500$, and $>500$ ppm-years, respectively. Although Paxton et al concluded that the data were consistent with a threshold model, the location of the threshold was not obvious from their analysis. ${ }^{78}$ They suggested a threshold of $50 \mathrm{ppm}$-years, as no significant excess of leukaemia was found below this exposure. In the analysis specific to AML in my report, no excess of AML was observed for cumulative exposure less than $200 \mathrm{ppm}$ years (SMR 0.91). Above this level risk of AML rose drastically, reaching a risk ratio of 98-fold for $>400$ ppm-years. If one considers a threshold as the level below which no excess risk is observed, then the data from the Pliofilm study indicate that the threshold for AML would be around 200 ppm-years.

Previous analyses of the Pliofilm study have been based on leukaemia of all cell types combined. Many regulatory policies have been based on such analyses. There are three major consequences of ignoring specific information on cell type in analysing risk of leukaemia. Firstly, the threshold based on all leukaemia cell types combined was less well defined and much lower than the one based on AML specifically. Secondly, above the threshold, the risk ratios based on all leukaemia cell types combined were substantially under estimated. Thirdly, by lumping all cell types into a single category, the misconception that benzene can increase the risk of other cell types of leukaemia may be created.

For cell types other than AML, the Pliofilm study does not provide sufficient cases for any meaningful analysis. The specific cell type with the second largest number of cases in the Pliofilm study was chronic myeloid leukaemia (CML), consisting of only two deaths. One of the two deaths from CML was employed at one of the plants for one month in 1948, and died two years later in 1950 at age 29. His cumulative exposure was 0.10 ppm-year. Clearly this case could not have been associated with exposure at the plant. Thus, the Pliofilm study offers little useful information on CML or other leukaemia cell types besides AML.

Several epidemiological studies have reported the lack of an association between exposure to benzene or mixtures containing benzene and other leukaemia cell types. ${ }^{18-22}$ For example, no association between CML and exposure to benzene or other organic solvents was found in case-control studies conducted in Sweden ${ }^{19}$ and in England. ${ }^{20}$ Similarly, case-control studies of CLL conducted in the Baltimore area ${ }^{21}$ and in four states in the United States (Washington, Utah, Michigan, and Georgia) ${ }^{22}$ did not detect any increased risk in people exposed to benzene.

The AML threshold of 200 ppm-years 
derived in this analysis is based on the exposure estimates of Rinsky et $a l^{4}{ }^{4}$ which are much lower than those developed by Crump and Allen ${ }^{5}$ or Paustenbach et $a l^{6}{ }^{6}$ although there was a high correlation between individual cumulative exposures based on the three sets of estimates. The Pearson correlation coefficient between cumulative exposures based on the estimates of Paustenbach et al and Rinsky et al $(0.83, \mathrm{P}<0.0001)$ was slightly higher than that between those from Crump and Allen and Rinsky et al $(0 \cdot 76, \mathrm{P}<$ $0.0001)$. The relations between the three sets of cumulative estimates are as follows:

$$
\begin{aligned}
& Y=13 \cdot 78+1 \cdot 78 \times X \text { and } \\
& Z=49 \cdot 43+2 \cdot 41 \times X,
\end{aligned}
$$

where $\mathrm{X}$ is the cumulative exposure based on the estimates of Rinsky et al, $\mathrm{Y}$ is that of Crump and Allen ${ }^{5}$ and $Z$ is that of Paustenbach et al. ${ }^{6}$ Based on the exposure estimates of Crump and Allen ${ }^{5}$ and Paustenbach et al, ${ }^{6}$ the AML thresholds would be about 370 and 530 ppm-years respectively.

A few reports in the scientific literature have suggested an association between exposure to benzene and multiple myeloma. Based on the Pliofilm study with mortality up to 1981, Rinsky et $\mathrm{al}^{4}$ reported a risk of borderline significance for multiple myeloma (SMR $3.98,95 \%$ CI $1 \cdot 10-10 \cdot 47)$. Cases of multiple myeloma in people with potential exposure to benzene have also been reported. ${ }^{23} 24$ These case reports do not provide any risk estimates, and therefore are not useful in causation analysis.

There were four deaths due to multiple myeloma in the Pliofilm study. One subject worked at one of the plants for four days, one for nine months, and another for 1.5 years. ${ }^{4}$ My analysis for multiple myeloma based on updated data shows that the significant excess previously reported by Rinsky et $a l^{4}$ was no longer significant. Furthermore, the exposureresponse analysis indicates that the deaths from multiple myeloma were not related to exposure to benzene at the plants in the study.

The lack of an association between exposure to benzene and multiple myeloma has been reported in several previous large scale studies. In a cohort study of more than 7000 chemical workers exposed to benzene, three deaths were reported from multiple myeloma, whereas about 2.6 deaths were expected. ${ }^{1011}$ In another cohort study of more than 18000 petroleum transportation workers exposed to petrol (containing $2 \%$ to $5 \%$ benzene), 17 deaths were reported from multiple myeloma, whereas 21.4 were expected. ${ }^{17}{ }^{25}$ Furthermore, several case-control studies have reported no increased risk of multiple myeloma among people exposed to benzene or benzene-containing solvents. ${ }^{25-30}$ For example, Linet et al reported a risk ratio of $1 \cdot 1$ for benzene exposure in a study in Baltimore, ${ }^{26}$ and Morris et al reported a risk ratio of 0.8 for aromatic hydrocarbons (benzene, toluene, xylene) in a study consisting of 698 cases in four states in the United States (Washington, Utah, Michigan, and Georgia). ${ }^{27}$ These studies support the analysis in my report.

Before closing, it should be pointed out that the number of deaths from AML or multiple myeloma included in my analyses was small, and therefore the results should be interpreted with caution and in conjunction with studies already mentioned. Nevertheless, previous analyses based on the same set of data have been relied upon by several regulatory agencies for policy making. These regulatory policies should be re-examined in view of the new analyses for AML and multiple myeloma presented in this report.

\section{Conclusion}

Three decades ago, Hill set forth criteria for assessment of causation. ${ }^{31}$ The same criteria were used in evaluating cancer risks related to tobacco in the Surgeon General's report on smoking, ${ }^{32}$ and by the International Agency for Research on Cancer in evaluation of carcinogenicity. ${ }^{33}$ Specificity is one of the major criteria for causation analysis. The analysis specific to AML presented in this report shows the importance of taking specificity into consideration. Previous analyses based on all leukaemia cell types combined have incorrectly set the estimated threshold too low but underestimated risk above the threshold. The estimated threshold specific to AML was found to be at least 200 ppm-years based on one set of exposure estimates; and much higher, had other exposure estimates (most likely more accurate) been used. Current regulatory policies relying on previous analyses based on all leukaemia cell types combined should be re-examined. The analysis on multiple myeloma shows that no significant increase was found, and that no exposure-response relation between exposure to benzene and multiple myeloma was detected. These results are consistent with findings from other epidemiological studies.

1 Infante PF, Rinsky RA, Wagoner JK, Young RJ. Leukemia in benzene workers. Lancet 1977;2:76-8.

2 Vigliani EC. Leukemia associated with benzene exposure. Ann N Y Acad Sci 1976;271:143-51.

Rinsky RA, Young RJ, Smith AB. Leukemia in benzene workers. Am ₹ Ind Med 1981;2:217-45.

4 Rinsky RA, Smith AB, Hornung R, Filloon TG, Young RJ, Okun AH, Landrigan PJ. Benzene and leukemia, an epidemiologic risk assessment. $N$ Engl $\mathcal{f}$ Med 1987;316: 1044-50.

5 Crump KS, Allen BC. Quantitative estimates of risk of leukemia from occupational exposure to benzene. Prepared for the Occupational Safety and Health Prepared for the Occupational Safety and Health Administration.

6 Paustenbach DJ, Price PS, Ollison W, Blank C, Jernigan JD, Bass RD, Peterson HD. Reevaluation of benzene exposure for the Pliofilm (rubberworkers) cohort (1936-1976). If Toxicol Environ Health 1992;36 177-231.

7 Paxton MB, Chinchill VM, Brett SM, Rodricks JV. Leukemia risk associated with benzene exposure in the Pliofilm cohort. I. Mortality update and exposure distribution. Risk Anal 1994;14:147-54.

8 Paxton MB, Chinchill VM, Brett SM, Rodricks JV. Leukemia risk associated with benzene exposure in the Pliofilm cohort. II. Risk estimates. Risk Anal 1994; 14:155-7.

9 Utterback DF, Rinsky RA. Cross-validation of multiple benzene exposure assessments for the rubber hydrochloride workers. zene exposure assessments for the rubber hydrochlonde workers. Presented at the Conference on Retrospective Assessment of
Occupational Exposures in Epidemiology. Lyon: Occupational Exposures in Epidemiology. Ly
International Agency for Research on Cancer, 1994. 
10 Wong $\mathrm{O}$. An industry-wide mortality study of chemical workers occupationally exposed to benzene. I Genera results. $\mathrm{Br}$ F Ind Med 1987;44:365-81.

11 Wong $O$. An industry-wide mortality study of chemica workers occupationally exposed to benzene. II Doseresponse analyses. $B r$ f Ind Med 1987;44:382-95.

12 Linet MS. The leukemias: epidemiologic aspects. Oxford: Oxford University Press, 1985

13 Heath CW. The leukemias. In: Schottenfeld D, Fraumeni JF, eds. Cancer epidemiology and prevention. Philadelphia: WB Saunders, 1982.

14 Wintrobe MM, Lee GR, Boggs DR, Bithell TC, Forester J, Athens JW, Lukens JN. Clinical hematology, 8th ed. J, Athens JW, Lukens JN. Clinical

15 Ford AM, Molgaard HV, Greaves MF, Gould HJ Immunoglobulin gene organization and expression in hemopoietic stem cell leukemia. EMBO 1983;2 997-1001.

16 Maher VE, Gill L, Townes PL, Wallace JE, Savas L, Woda BA, Ansell JE. Simultaneous chronic lymphocytic leukemia and chronic myelogenous leukemia. Cancer 1993;71:1993-7.

17 Irons RD, Stillman WS, Colagiovanni DB, Henry VAS Synergistic action of the benzene metabolite, hydroquinone, on myelopoietic stimulation activity of hydroquinone, on myelopoietic stimulation activity of granulocyte/macrophage colony stimula
vitro. Proc Natl Acad Sci 1992;89:3691-5.

18 Wong O, Harris F, Smith TJ. Health effects of gasoline exposure. II Mortality patterns of distribution workers in the United States. Environ Health Perspect 1993;101 (suppl 6):63-76.

19 Brandt L, Nilsson PG, Mitelman F. Occupational exposure to petroleum products in men with acute nonlymphocytic leukemia. $B M \mathcal{F} 1978 ; 1: 553$.

20 McKinney PA, Roberts BE, O'Brien C, Bird CC Richards IDG, Alexander F, Cartwright RA. Chronic myeloid leukemia in Yorkshire: a case control study. Acta Haematol 1990;83:35-8.

21 Linet MS, Stewart WF, Van Natta ML, McCaffrey LD, Szklo M. Comparison of methods for determining occupational exposure in a case-control interview study of chronic lymphocytic leukemia. $尹$ Occup Med 1987;29. 136-41
22 Malone KE, Koepsell TD, Daling JR, Weiss NS, Morris PD, Taylor JW, et al. Chronic lymphocytic leukemia in relation to chemical exposures. Am f Epidemiol 1989, 130:1152-8.

23 Torres A, Grilat M, Raichs A. Coexistencia de antecedentes benzólicos crónicos y plasmocitoma múltiple. Presentación de dos casos. Sangre 1970;15:275-9.

24 Aksoy M, Erdem \$, Dinçol G, Kutlar A, Bakioglu I, Hepyüksel. Clinical observations showing the role of some factors in the etiology of multiple myeloma. Acta Haematol 1984;71:116-20.

25 Wong O, Trent L. A nested case-control study of kidney cancer, leukemia and multiple myeloma in a cohort of land-based leukeminal workers exposed to gasoline in the petroleum terminal workers exposed to gasoline in the petroleum
industry. Washington, DC: American Petroleum industry. Was

26 Linet MS, Harlow SD, McLaughlin JK. A case-control study of multiple myeloma in whites: chronic antigenic stimulation, occupation, and drug use. Cancer Res 1987;44:2978-81.

27 Morris PD, Koepsell TD, Daling JR, Taylor JW, Lyon JL Swanson GM, et al. Toxic substance exposure and multiple myeloma: a case-control study. $\mathcal{F}$ Natl Cancer Inst 1986;76:987-94.

28 Cuzick J, De Stavola B. Multiple myeloma-a case-control study. Br $f$ Cancer 1988;57:516-20.

29 Eriksson M, Karlsson M. Occupational and other environmental factors and multiple myeloma: a population based case-control study. $\mathrm{Br} F$ Ind Med 1992;49. 95-103.

30 Flodin U, Fredriksson M, Persson B. Multiple myeloma and engine exhausts, fresh wood, and creosote: a casereferent study. Am F Ind Med 1987;12:519-29.

31 Hill AB. The environment and disease: association or causation? Proceedings of the Royal Society of Medicine 1965;58:295-300.

32 Surgeon General. Smoking and health. Washington, DC US Governmental Printing Office, 1964.

33 International Agency for Research on Cancer. IARC Monographs on the Evaluation of Carcinogenic Risks to Humans, occupational exposures in petroleum refining. crude oil and major petroleum fuels. Vol 45. Lyon: IARC, 1989 .

\section{Correspondence and editorials}

Occupational and Environmental Medicine welcomes correspondence relating to any of the material appearing in the journal. Results from preliminary or small scale studies may also be published in the correspondence column if this seems appropriate. Letters should be not more than 500 words in length and contain a minimum of references. Tables and figures should be kept to an absolute minimum. Letters are accepted on the understanding that they may be subject to editorial revision and shortening.

The journal also publishes editorials which are normally specially commissioned. The Editor welcomes suggestions regarding suitable topics; those wishing to submit an editorial, however, should do so only after discussion with the Editor. 